\title{
Longitudinal study of heart size in older people
}

\author{
I. J. Lauder and J. S. Milne \\ From the Geriatric Research Unit, Royal Victoria Hospital, Edinburgh; and the MRC Clinical and \\ Population Cytogenetics Unit, Edinburgh
}

\begin{abstract}
Transverse cardiac diameter and transverse thoracic diameter were measured in a longitudinal study of older men and women at the original examination and after five years. The cardiothoracic ratio overestimated 5year changes in heart size, because of significant decreases with age in transverse thoracic diameter. A regression equation to predict transverse cardiac diameter from age and weight had been previously computed from the data obtained at the initial examination. This was a satisfactory predictor of recorded 5-year changes except in women of 70 years and over at entry to the study in whom the predicted change was significantly larger than the recorded change. This had resulted from the death during the 5 years of women in that age group with larger transverse cardiac diameters.
\end{abstract}

A previous paper described measurements of transverse cardiac diameter and transverse chest diameter in a random sample of older people (Milne and Lauder, 1974). The conclusion drawn from analysis of these cross-sectional data was that the cardiothoracic ratio was an unsatisfactory estimate of heart size in the elderly because of decrease in the transverse chest diameter as age increased. Transverse cardiac diameter was a better estimate of heart size, and equations were derived to predict this diameter from age and weight. In both sexes, the transverse cardiac diameter increased significantly as age increased.

The present paper describes the result of remeasurement of the survivors of the original study after 5 years. A comparison has also been made of cross-sectional with longitudinal data.

\section{Methods}

The original study was made on 215 men and 272 women aged 62 to 90 years who formed a simple random sample from 27000 older people living in a defined area of Edinburgh. The method of sampling has been fully described elsewhere (Milne, Maule, and Williamson, 1971). The persons examined in the present study were those members of the original sample who were alive after 5 years and who were willing to attend for re-examination. These numbered 113 men and 148 women. The follow-up of persons in the sample has been fully

Received 5 April 1976. described elsewhere (Milne and Chopin, 1975).

Posteroanterior chest $x$-rays were taken at both examinations, at a tube-film distance of $183 \mathrm{~cm}$ $(6 \mathrm{ft})$ at the height of a less than maximal inspiration. The transverse cardiac diameter and the transverse chest diameter were measured to the nearest millimetre on the films, using a Harpenden anthropometer (Tanner and Whitehouse, 1957) with straight branches. This sliding caliper allowed measurement of the transverse cardiac diameter in one simple operation (Milne and Lauder, 1974). The transverse chest diameter was measured from the internal surfaces of the ribs, superior to the costal attachment of the diaphragm, at the point where the chest width was greatest (Cowan, 1959). Suitable measurements of cardiac diameter were obtained in 113 men and 139 women and of chest diameter in 95 men and 137 women. The cardiothoracic ratio was expressed as $100 \times$ (transverse cardiac diameter/ transverse chest diameter). In the original sample the mean cardiac diameter was significantly larger in persons with diastolic pressures of $100 \mathrm{mmHg}$ or more. This was no longer true in the 5-year examination and measurements of persons with these pressures ( 5 men, 18 women) were not excluded from the analysis. Unpublished data from the study show that the mean diastolic blood pressure in survivors after 5 years is significantly lower than at the original examination.

Reproducibility of the measurements was satisfactory. The method of testing this has been fully described elsewhere (Milne and Lauder, 1974). 


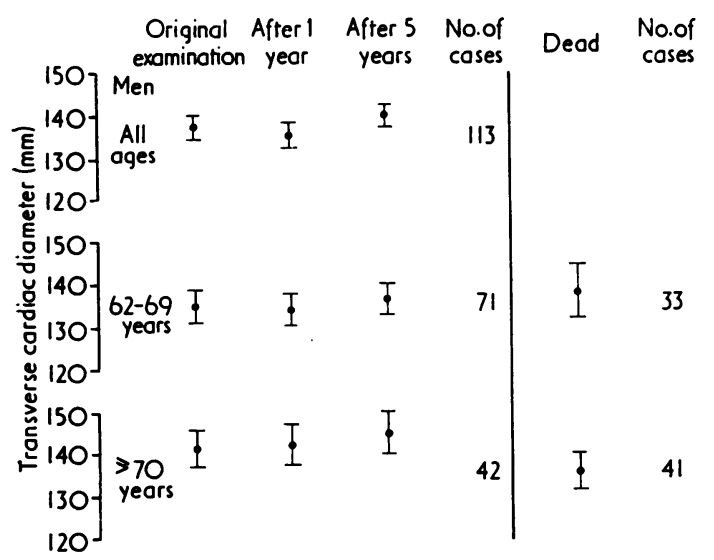

FIG. 1. Mean transverse cardiac diameters with 95 per cent confidence limits in surviving men in a longitudinal study, and in those who died.

\section{Results}

Mean values of transverse cardiac diameter with 95 per cent confidence limits are given for men in Fig. 1 and for women in Fig. 2. Apart from the dead all measurements refer to those survivors who were examined after 5 years and ages given are on entry to the study. The age categories were 'below 70 years' and ' 70 years and over'.

The mean values suggested an increase in cardiac diameter over the 5-year period, but this did not reach statistical significance. In the men and younger women who died, cardiac diameters at the original examination did not differ from those in survivors. In women who died and who were 70 years and over on entry to the study, the mean cardiac diameter was significantly greater at the original examination than in surviving women of the same age group, both at the original examination and when measured again five years later.

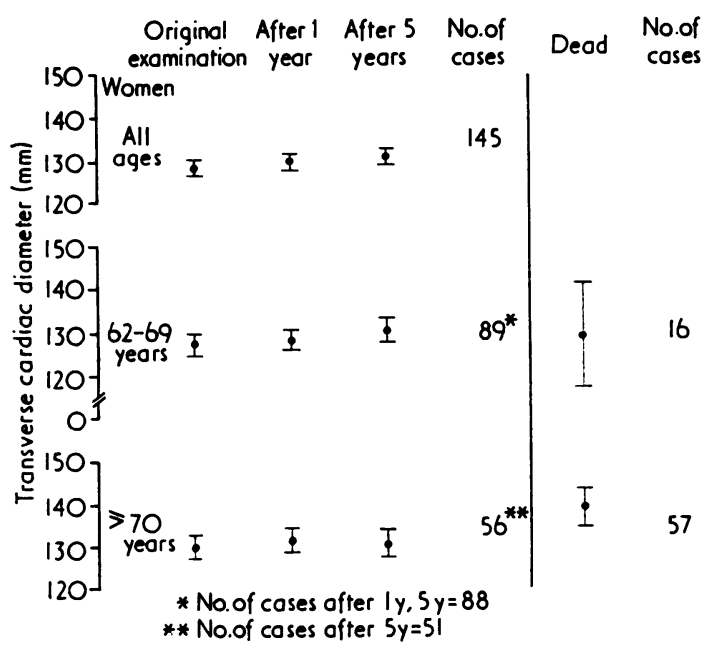

FIG. 2. Mean transverse cardiac diameters with 95 per cent confidence limits in surviving women in a longitudinal study, and in those who died.

Mean values and 95 per cent confidence limits of transverse chest diameter were similarly examined. No significant difference was found, when comparing appropriate age groups, among surviving or dead subjects. These values are, therefore, not reported further.

In each surviving subject the measurement of transverse cardiac diameter at the original examination was subtracted from the measurement at the 5 -year examination. This was done also for the transverse chest diameter and for the cardiothoracic ratio. Mean differences with standard errors of these three variables are given in Table 1. Student's two-tail $t$ test was used to test whether mean differences differed significantly from zero.

The tests showed that the mean differences in the cardiac diameter in 5 years were significant in men of 70 years and over $(P<0.05)$ and in women of 62 to 69 years $(P<0 \cdot 001)$. The ages are those

TABLE 1 Mean differences in transverse cardiac diameter, transverse chest diameter, and cardiothoracic ratio, after 5 years, in two age groups of older men and women

\begin{tabular}{|c|c|c|c|c|c|c|c|c|c|}
\hline $\begin{array}{c}\text { Age } \\
\text { (at entry) }\end{array}$ & $\begin{array}{l}\text { Cardiac dic } \\
\text { Mean } \\
\text { difference }\end{array}$ & $\underset{S E}{\operatorname{meter}}(\mathrm{mm})$ & $\begin{array}{l}\text { No. of } \\
\text { cases }\end{array}$ & $\begin{array}{l}\text { Chest diam } \\
\text { Mean } \\
\text { difference }\end{array}$ & $\begin{array}{l}\operatorname{ter}(m m) \\
S E\end{array}$ & $\begin{array}{l}\text { No. of } \\
\text { cases }\end{array}$ & $\begin{array}{l}\text { Cardiothor } \\
\text { Mean } \\
\text { difference }\end{array}$ & $\begin{array}{l}\text { cic ratio }(\%) \\
S E\end{array}$ & $\begin{array}{l}\text { No. of } \\
\text { cases }\end{array}$ \\
\hline \multicolumn{10}{|l|}{ Men } \\
\hline $\begin{array}{l}62 \text { to } 69 y \\
\geqslant 70 y\end{array}$ & $\begin{array}{l}1 \cdot 282 \\
3 \cdot 643^{\star}\end{array}$ & $\begin{array}{l}1.035 \\
1.509\end{array}$ & $\begin{array}{l}71 \\
42\end{array}$ & $\begin{array}{l}-2 \cdot 421^{\star} \\
-1 \cdot 237\end{array}$ & $\begin{array}{l}1 \cdot 161 \\
2 \cdot 184\end{array}$ & $\begin{array}{l}57 \\
38\end{array}$ & $\begin{array}{l}1.137^{\star} \\
1.253^{\star}\end{array}$ & $\begin{array}{l}0.436 \\
0.552\end{array}$ & $\begin{array}{l}57 \\
38\end{array}$ \\
\hline \multicolumn{10}{|l|}{ Women } \\
\hline $\begin{array}{l}62 \text { to } 69 y \\
\geqslant 70 y\end{array}$ & $\begin{array}{l}3 \cdot 483^{\star \star \star} \\
1 \cdot 784\end{array}$ & $\begin{array}{l}0.793 \\
1.228 \\
\end{array}$ & $\begin{array}{l}88 \\
51\end{array}$ & $\begin{array}{l}-2 \cdot 553^{\star} \\
-3 \cdot 462^{\star \star}\end{array}$ & $\begin{array}{l}1 \cdot 108 \\
1 \cdot 194\end{array}$ & $\begin{array}{l}85 \\
52\end{array}$ & $\begin{array}{l}1 \cdot 939 \star \star \star \\
1 \cdot 439 \star \star \star\end{array}$ & $\begin{array}{l}0.407 \\
0.461\end{array}$ & $\begin{array}{l}85 \\
51\end{array}$ \\
\hline
\end{tabular}


TABLE 2 Regressions of transverse cardiac diameter on age and body weight in various groups of older men and women

\begin{tabular}{|c|c|c|c|c|c|c|}
\hline $\begin{array}{l}\text { Sex and } \\
\text { age }\end{array}$ & Group examined and time of examination & Intercept & $\begin{array}{l}\text { Regression } \\
\text { coefficient } \\
\text { (age) }\end{array}$ & $\begin{array}{l}\text { Regression } \\
\text { coefficient } \\
\text { (weight) }\end{array}$ & $R$ & $\begin{array}{l}\text { No. of } \\
\text { cases }\end{array}$ \\
\hline \multicolumn{7}{|l|}{ Men } \\
\hline 62 to $90 \mathrm{y}$ & $\begin{array}{l}\text { All men at original examination } \\
5 \text {-year survivors at original examination } \\
\text { Dead (after } 5 \text { years) at original examination } \\
5 \text {-year survivors at 5-year examination }\end{array}$ & $\begin{array}{l}61 \cdot 762 \\
58 \cdot 581 \\
57 \cdot 346 \\
47 \cdot 781\end{array}$ & $\begin{array}{l}0.413 \\
0.372 \\
0.485 \\
0.699\end{array}$ & $\begin{array}{l}0.692 \\
0.762 \\
0.719 \\
0.643\end{array}$ & $\begin{array}{l}0.62 \\
0.65 \\
0.57 \\
0.57\end{array}$ & $\begin{array}{r}188^{\star} \\
113 \\
74 \\
113\end{array}$ \\
\hline \multicolumn{7}{|c|}{ 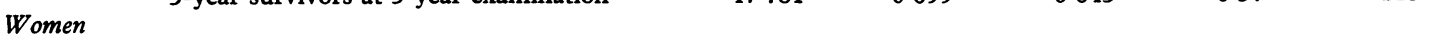 } \\
\hline 62 to $90 \mathrm{y}$ & $\begin{array}{l}\text { All women at original examination } \\
5 \text {-year survivors at original examination } \\
\text { Dead (after } 5 \text { years) at original examination } \\
\text { 5-year survivors at 5-year examination }\end{array}$ & $\begin{array}{l}42 \cdot 942 \\
70 \cdot 003 \\
20 \cdot 876 \\
94 \cdot 339\end{array}$ & $\begin{array}{l}0.646 \\
0.334 \\
0.930 \\
0.111\end{array}$ & $\begin{array}{l}0 \cdot 661 \\
0.567 \\
0 \cdot 766 \\
0 \cdot 481\end{array}$ & $\begin{array}{l}0.61 \\
0.57 \\
0.64 \\
0.44\end{array}$ & $\begin{array}{l}201^{\star} \\
145 \\
52 \\
139\end{array}$ \\
\hline
\end{tabular}

$\star$ Excludes persons with diastolic $\mathrm{BP} \geqslant 100 \mathrm{mmHg}$ (see text).

All regression coefficients were significant except that for age in women 5-year survivors at the 5-year examination.

at entry to the study. Significant differences in the mean chest diameter were found in all groups except men of 70 years and over. Differences in the mean cardiothoracic ratio occurred in both groups of men $(P<0.05)$ and of women $(P<0.001)$. When the signs of the differences are taken into account, the findings of the analysis are increases with age in mean heart size estimated by the cardiothoracic ratio in all groups, but increases in mean cardiac diameter only in older men and younger women. The difference in behaviour of these two variables is the result of the different levels of decrease in transverse chest diameter (Table 1). The large number of missing values of transverse chest diameter is the result of failure to include the whole width of male thoraces on some of the films taken at the original examination.

Data collected at the original examination from all persons taking part then, except those with diastolic blood pressure of $100 \mathrm{mmHg}$ or more, were used to derive an equation to predict transverse cardiac diameter from age and body weight (Milne and Lauder, 1974). The regression coefficients are shown in Table 2, rows 1 and 5.

A similar equation was derived, for 5-year survivors, with age and body weight as the independent variables, using the data which had been collected at the original examination (Table 2, rows 2 and 6). In men the regression coefficients were similar to those in the first equation based on the whole sample, while in women, though the coefficient of regression on body weight was similar, the coefficient of regression on age was about half the value of that in the equation based on the whole sample.

An equation was similarly derived, using data obtained at the original examination from persons who died during the 5 years of the study (Table 2, rows 3 and 7); again regression coefficients in men resembled those in the first equation in Table 2, but in women the coefficient of regression on age was larger than that in the first equation. These differences in the coefficients of regression on age in women, though not statistically significant, suggest larger cardiac diameters in older women who died.

Finally, the regression of transverse cardiac diameter on age and body weight was calculated in surviving men and women using data gathered at the 5-year examination (Table 2, rows 4 and 8). Once again in men the regression coefficients were similar to those in the first equation in Table 2 but in women age ceased to make a significant contribution to the regression. This again suggested a loss from the sample of older women with larger hearts.

To test this hypothesis the regressions of transverse cardiac diameter on age and body weight based on the original data (Table 2, rows 1 and 4) were used to calculate the expected cardiac diameter in survivors examined 5 years after the original examination. The age used in the equation was age at entry plus 5 years. This predicted value was subtracted in each subject from the transverse cardiac diameter recorded at the 5-year examination (Table 3). This Table shows reasonable agreement between predicted and actual values except in women aged 70 years and over at original examination, in whom the mean predicted value was significantly larger than the mean recorded value.

The mean cardiac diameter was next examined using the original data, in the dead and in the survivors of men and women in both age groups on entry to the study. These survivors were not only those re-examined after 5 years but also included those who survived and after the first examination 
TABLE 3 Transverse cardiac diameter in older men and women recorded after 5 years minus diameter pre-

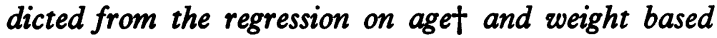
on original data

\begin{tabular}{|c|c|c|c|c|c|c|}
\hline $\begin{array}{l}\text { Sex and age } \\
\text { (at entry) }\end{array}$ & \multicolumn{3}{|c|}{$\begin{array}{l}\text { Mean } \\
\text { difference } \\
(\mathrm{mm})\end{array}$} & \multicolumn{2}{|l|}{$S D$} & $\begin{array}{l}\text { No. of } \\
\text { cases }\end{array}$ \\
\hline \multicolumn{7}{|l|}{ Men } \\
\hline $\begin{array}{l}62 \text { to } 69 y \\
\geqslant 70 y\end{array}$ & \multicolumn{3}{|c|}{$\begin{array}{r}-0.977 \\
1.608\end{array}$} & \multicolumn{2}{|l|}{$\begin{array}{l}12 \cdot 315 \\
12 \cdot 191\end{array}$} & $\begin{array}{l}69 \\
39\end{array}$ \\
\hline \multicolumn{7}{|l|}{ Women } \\
\hline $\begin{array}{l}62 \text { to } 69 y \\
\geqslant 70 y\end{array}$ & \multicolumn{3}{|c|}{$\begin{array}{c}0.323 \\
-3.631 \star\end{array}$} & \multicolumn{2}{|l|}{$\begin{array}{l}9.984 \\
9.957\end{array}$} & $\begin{array}{l}76 \\
44\end{array}$ \\
\hline \multicolumn{7}{|c|}{$\begin{array}{l}\text { *P }<0.05 \\
\text { †Age used in regression equals age at entry }+5 \text { years. }\end{array}$} \\
\hline \multicolumn{7}{|c|}{$\begin{array}{l}\text { TABLE } 4 \text { Transverse cardiac diameter at origina } \\
\text { examination in two age groups of men and womer } \\
\text { separated into those who died and those who were alive } \\
5 \text { years later }\end{array}$} \\
\hline $\begin{array}{l}\text { Sex and } \\
\text { age } \\
\text { (at entry) }\end{array}$ & $\begin{array}{l}\text { Alive } \\
\text { Mean } \\
(\mathrm{mm})\end{array}$ & $S E$ & $\begin{array}{l}\text { No. of } \\
\text { cases }\end{array}$ & $\begin{array}{l}\text { Dead } \\
\text { Mean } \\
(\mathrm{mm})\end{array}$ & $S E$ & $\begin{array}{l}\text { No. of } \\
\text { cases }\end{array}$ \\
\hline \multicolumn{7}{|l|}{ Men } \\
\hline $\begin{array}{l}62 \text { to } 69 y \\
\geqslant 70 y\end{array}$ & $\begin{array}{l}136 \cdot 2 \\
142 \cdot 6\end{array}$ & $\begin{array}{l}1.50 \\
1.96\end{array}$ & $\begin{array}{l}88 \\
49\end{array}$ & $\begin{array}{l}139 \cdot 0 \\
136 \cdot 7\end{array}$ & $\begin{array}{l}2 \cdot 91 \\
2 \cdot 21\end{array}$ & $\begin{array}{l}33 \\
41\end{array}$ \\
\hline \multicolumn{7}{|l|}{ Women } \\
\hline $\begin{array}{l}62 \text { to } 69 y \\
\geqslant 70 y\end{array}$ & $\begin{array}{l}128 \cdot 2 \\
128 \cdot 8\end{array}$ & $\begin{array}{l}1 \cdot 18 \\
1 \cdot 36\end{array}$ & $\begin{array}{r}118 \\
86\end{array}$ & $\begin{array}{l}129 \cdot 5 \\
139 \cdot 7 \star \star\end{array}$ & $\begin{array}{r}5 \cdot 66 \\
+2 \cdot 30\end{array}$ & $\begin{array}{l}16 \\
37\end{array}$ \\
\hline
\end{tabular}

$\star \star \mathbf{P}<0.01$.

were lost to the study for reasons other than death. Table 4 gives mean values with standard errors for these groups. The mean values in the dead and the survivors did not differ significantly except in women of 70 years and over $(P<0.01$, two-tail test). In this group the mean cardiac diameter of the dead women appeared to be larger than that of the survivors. This confirmed the impression, described above, gained from studying coefficients of regression of cardiac diameter on age, using the data from the original examination, in women who survived for 5 years and in those who died.

Mean cardiac diameters were compared in men and in women, aged 62 to 69 and 70 years and over on entry to the study, who were recorded as dying of heart disease and of diseases other than heart disease during the subsequent 5 years (Table 5). A significant difference $(P<0.05)$ in the transverse cardiac diameter was found only comparing women of 70 years and over who died of heart disease with those who died of another cause. In these women the
TABLE 5 Transverse cardiac diameter related to cause of death in two age groups of older men and women

\begin{tabular}{|c|c|c|c|c|}
\hline $\begin{array}{l}\text { Sex and } \\
\text { age } \\
\text { (at entry) }\end{array}$ & Cause of death & $\begin{array}{l}\text { Cardiac } \\
\text { Mean } \\
(\mathrm{mm})\end{array}$ & $\begin{array}{l}\text { diameter } \\
S D\end{array}$ & $\begin{array}{l}\text { No. of } \\
\text { cases }\end{array}$ \\
\hline \multicolumn{5}{|l|}{ Men } \\
\hline $\begin{array}{l}62 \text { to } 69 y \\
\geqslant 70 y\end{array}$ & $\begin{array}{l}\text { Heart disease } \\
\text { No heart disease } \\
\text { Heart disease } \\
\text { No heart disease }\end{array}$ & $\begin{array}{l}142 \cdot 4 \\
140 \cdot 1 \\
140 \cdot 8 \\
134 \cdot 9\end{array}$ & $\begin{array}{l}20 \cdot 01 \\
15 \cdot 51 \\
12 \cdot 35 \\
14 \cdot 63\end{array}$ & $\begin{array}{l}11 \\
20 \\
12 \\
29\end{array}$ \\
\hline \multicolumn{5}{|l|}{ Women } \\
\hline $\begin{array}{l}62 \text { to } 69 y \\
\geqslant 70 y\end{array}$ & $\begin{array}{l}\text { Heart disease } \\
\text { No heart disease } \\
\text { Heart disease } \\
\text { No heart disease }\end{array}$ & $\begin{array}{l}(152 \cdot 0) \\
126 \cdot 3 \\
148 \cdot 1 \\
134 \cdot 5\end{array}$ & $\begin{array}{l}\overline{16} \cdot 70 \\
14 \cdot 87 \\
11 \cdot 02\end{array}$ & $\begin{array}{l}(2) \\
14 \\
14 \\
22\end{array}$ \\
\hline
\end{tabular}

mean transverse cardiac diameter was larger in the group who died of heart disease; no significant difference was found in the other three groups.

\section{Discussion}

This study has confirmed from a 5-year follow-up what was suspected from cross-sectional data (Milne and Lauder, 1974), namely that the cardiothoracic ratio overestimates changes in heart size in the elderly. The data given above suggest that this is because of decrease in transverse thoracic diameter in many people as age increases. Other workers have also thought, on the basis of cross-sectional studies, that transverse thoracic diameter decreases with increasing age (Cowan, 1959; Mayer, Blazsik, and Rappaport, 1958; Edge et al., 1964) but longitudinal studies such as the present one are a more certain method of confirming the hypothesis.

The various methods of data analysis used above suggested that the greatest difference between changes in cardiac diameter predicted from age differences in a cross-sectional study of the elderly and the actual changes recorded after 5 years, was found in women 70 years and over on entry to the study. This resulted from the death of women in this age group who had larger cardiac diameters. In the same age group of women the mean cardiac diameter was larger in those whose deaths were the result of heart disease than in those whose deaths were from other causes.

The regression of transverse cardiac diameter on age and weight based on cross-sectional data from men in the present study has been a reasonable predictor of changes in cardiac diameter over 5 years. In women a similar equation predicted 5-year changes greater than those that actually occurred. The loss by death of older women with larger 
cardiac diameters eliminated age from the regression in the survivors. Though the present study offers no confirmatory data, one might speculate that the difference described between men and women was a reflection of different time relations in the sexes between heart disease and mortality.

The increase in transverse cardiac diameter over 5 years in women aged 62 to 69 years at entry to the study does not preclude the possibility that the relation observed in this sample between transverse cardiac diameter and mortality in women aged 70 years and over at entry to the study may be a general phenomenon in the female population.

This study was supported by a grant from the Secretary of State for Scotland.

\section{References}

Cowan, N. R. (1959). The heart lung coefficient in older people. British Heart Fournal, 21, 238.
Edge, J. R., Millard, F. J. C., Reid, L., and Simon, G. (1964). The radiographic appearances of the chest in persons of advanced age. British fournal of Radiology, 37, 769.

Mayer, E., Blazsik, C., and Rappaport, I. (1958). Emphysema and the lungs of the aged. Diseases of the Chest, 34, 247.

Milne, J. S., and Chopin, J. M. (1975). Reviews after one and five years in a longitudinal study of ageing persons. Age and Ageing, 4, 152.

Milne, J. S., and Lauder, I. J. (1974). Heart size in older people. British Heart fournal, 36, 352.

Milne, J. S., Maule, M. M., and Williamson, J. (1971). Method of sampling in a study of older people with a comparison of respondents and non-respondents. British Fournal of Preventive and Social Medicine, 25, 37.

Tanner, J. M., and Whitehouse, R. H. (1957). The Harpenden anthropometer: a counter-type anthropometric caliper. American fournal of Physical Anthropometry, 15, 277.

Requests for reprints to Dr. J. S. Milne, East Fortune Hospital, North Berwick, East Lothian EH39 5JX. 